This item was submitted to Loughborough's Research Repository by the author.

Items in Figshare are protected by copyright, with all rights reserved, unless otherwise indicated.

\title{
The performance implications of strategic capital for public leisure providers
}

PLEASE CITE THE PUBLISHED VERSION

http://dx.doi.org/10.1080/02642069.2011.567413

PUBLISHER

(C) Taylor \& Francis

VERSION

AM (Accepted Manuscript)

LICENCE

CC BY-NC-ND 4.0

REPOSITORY RECORD

Hodgkinson, lan R., and Paul Hughes. 2019. "The Performance Implications of Strategic Capital for Public Leisure Providers”. figshare. https://hdl.handle.net/2134/14973. 
This item was submitted to Loughborough's Institutional Repository (https://dspace.lboro.ac.uk/) by the author and is made available under the following Creative Commons Licence conditions.

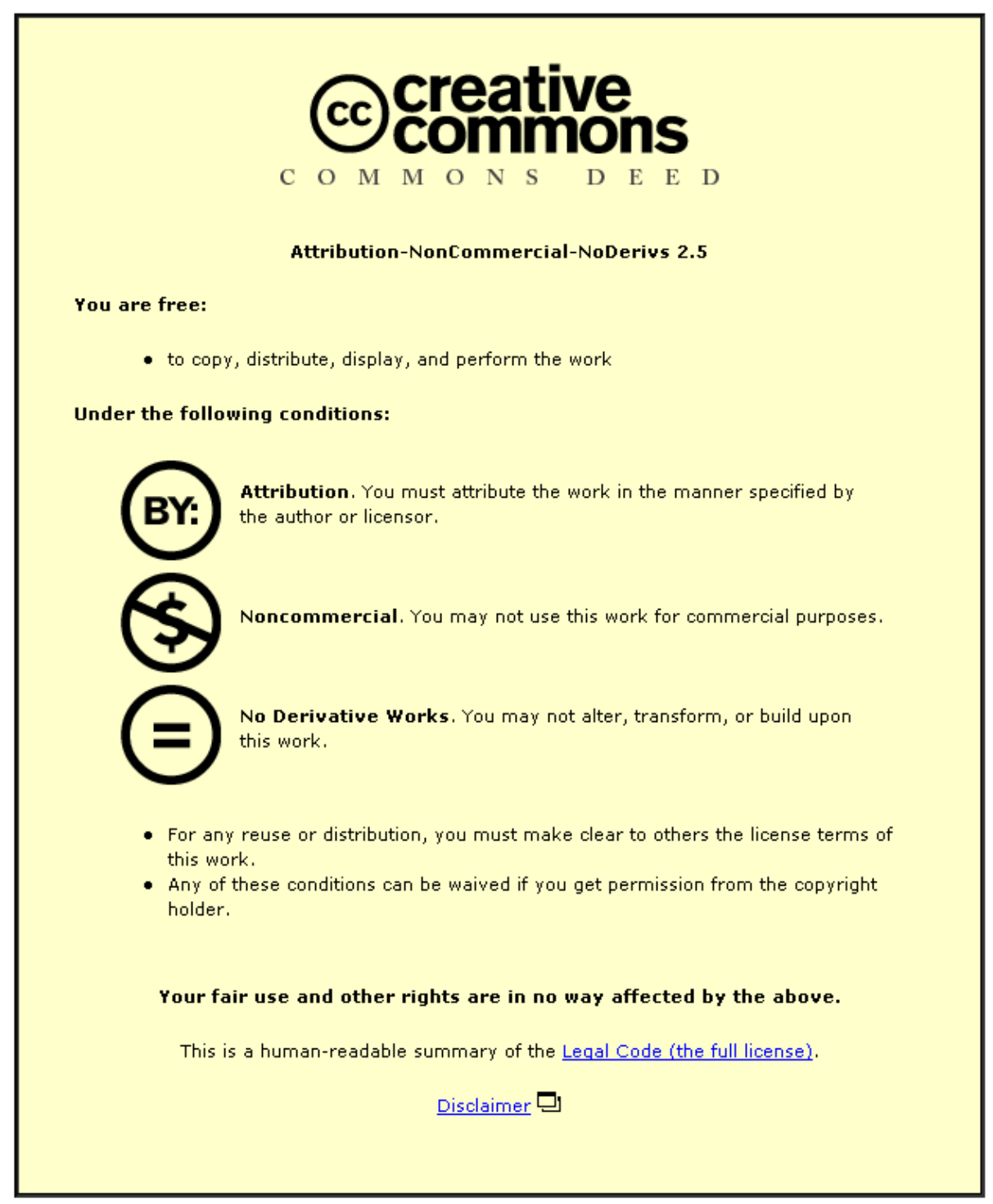

For the full text of this licence, please go to: http://creativecommons.org/licenses/by-nc-nd/2.5/ 


\title{
The Performance Implications of Strategic Capital for Public Leisure Providers
}

\section{Ian R. Hodgkinson}

School of Business and Economics, Loughborough University, Loughborough, UK.

\section{Paul Hughes}

School of Business and Economics, Loughborough University, Loughborough, UK.

\begin{abstract}
Strategic capital has emerged as a key source of competitive heterogeneity in the private sector. Despite this, little is known about the performance implications of strategic capital in public organisations. Adopting a resource-advantage perspective, we examine the performance implications of strategic capital for public leisure providers. Analysing data generated from public leisure providers, we find that effective strategy implementation enables leisure providers to exploit comparative advantages which, is itself, a source of sustained advantage. Further, high performers are endowed with significantly greater levels of strategic capital-that include 'strategy commitment', ‘implementation support', ‘implementation effectiveness’, and ‘ learning'-in contrast with low performers. Important differences between internal and external approaches to provision are also identified and discussed, along with the implications of this study for researchers and public policy.
\end{abstract}

Key words: resource-advantage theory; public leisure provision; strategic capital; business performance.

This is an Author's Original Manuscript of an article whose final and definitive form, the Version of Record, has been published in the Service Industries Journal 2012 [copyright Taylor \& Francis], available online at: http://www.tandfonline.com/doi/abs/10.1080/02642069.2011.567413 


\section{Introduction}

Resource-based theory seeks to explain how organisations develop strategies to effectively utilise and deploy resources with the aim to achieve competitive advantage (Sanchez, Heene, \& Thomas, 1996). The underlying assumption is that resources which are both significantly heterogeneous across firms and imperfectly mobile can generate competitive advantage and superior financial performance (Hunt \& Lambe, 2000). However, it is recognised that purely possessing a valuable resource alone does not allow the organisation to achieve a competitive advantage; rather, it is necessary to develop and position all value creating, tangible and intangible entities through a specified strategy (Hughes \& Morgan, 2007). This school of thought has been promoted within the resource-advantage theory (hereafter R-A theory) (Hunt, 2000; Hunt \& Morgan, 1995, 1996). R-A theory is an evolutionary approach to studying sustained strategic advantages from a resource perspective. The capital metaphor is used in management disciplines to refer to resources within the organisation that contribute to value creation. To achieve a sustainable advantageous position, the organisation must use bundles of resources (which together form the capital base) that are hard for competitors to imitate or acquire; these resources should therefore be mostly intangible and can be referred to as strategic (Hughes \& Morgan, 2007). Examples of strategic capital from R-A theory include organisational learning, relationships (with stakeholders, government agencies), entrepreneurial skills and capabilities (e.g., implementation capabilities), which enable the organisation to produce efficiently and/or effectively a market offering that has value, leading to a competitive advantage (Seggie \& Griffith, 2007; Hunt \& Lambe, 2000). Consistent with R-A theory, when a comparative advantage in capital is exhibited, all else equal, 
better performance should follow (Griffith, Yalcinkaya, \& Calantone, 2010; Hughes \& Morgan, 2007).

Research examining the effects of resources and capital on performance in private organisations is substantial and strategic capital has emerged as a key source of competitive heterogeneity (Hughes \& Morgan, 2007, 2008). Despite this, little is known about the performance implications of strategic capital in public organisations. There are increasing expectations of public organisations to improve performance, as seen in the modernisation agenda in the UK (Boyne \& Walker, 2004). In the face of funding cuts (Reid, 2003), it is by necessity that strategic approaches in the public sector focus on internal resources (Pablo, Reay, Dewald, \& Casebeer, 2007) as a means to improve service provision and thus, performance. It is apparent then that public leisure providers need to better understand how to exploit their strategic capital base.

The purpose of this study is to examine strategic capital in public leisure organisations and determine whether strategic capital dimensions accrue performance returns for public leisure providers. To this end, R-A theory provides a theoretical lens for an examination of strategic capital. Consistent with Hughes and Morgan (2007), we contend that strategic capital, comprised of intangible strategic resources, can be leveraged to improve the performance of public leisure providers. Further, we compare and contrast the strategic capital base and performance of internal and external service providers and contend that the superior performing provider will be endowed with significantly greater levels of strategic capital.

\section{Literature review}


Public sector managers are expected to use managerial strategies to improve organisational performance (Pablo et al., 2007), since they increasingly face the same economic pressures to survive as private sector organisations (Clohesy, 2003); particularly within the current local government environment of funding cuts (Reid, 2003). The need to improve performance despite reduced financial resources from local government has required that strategic approaches by necessity focus on internal resources (Pablo et al., 2007). Consistent with Pablo et al. (2007) and established works in the strategy literature, strategy is concerned with the deployment of available resources to maximise performance.

R-A theory was developed as a means to go beyond the resource-based view (RBV) and its perceived deficiencies and explain why [public or private] organisations, countries or even continents have comparative advantages that lead to dominant positions and superior performance relative to similarly endowed but underperforming entities (Griffith et al., 2010; Hughes \& Morgan, 2007; Hunt, 2000; Hunt \& Morgan, 1995, 1996). Crucially, R-A theory deviates away from existing theories by stressing three key points: (1) for any given resource to be strategic it must enable a firm (or country or an entity) to produce efficiently and/or effectively an offering that creates value to its target market; (2) for any given resource to be strategic it must be deployable in a strategy. This deviates away from the RBV which stresses possession of key resources is enough for competitive advantage; (3) R-A theory provides a breakdown of precisely what types of resources and capabilities can constitute strategic resources or indeed, strategic capital. This was beyond the realms of RBV as it only laid out certain criteria. Specifically, R-A theory indicates that various forms of human (e.g., employee skills, learning, commitment and training), informational (e.g., knowledge, understanding of markets, customers etc.), relational 
(e.g., relationships, alliances and cooperative agreements) and organisational capital (e.g., culture, firm resources and capabilities) together form 'strategic capital' (Hughes \& Morgan, 2007; Hunt, 2000).

Research into R-A theory has predominantly examined private sector organisations and this presents a limitation in the literature as we do not yet understand the effects of strategic capital and R-A theory in the public sector. It is clear from Hunt and Morgan (1995) and Hunt (2000) that governmental policies and actions can directly impact upon public sector organisations' comparative advantages in strategic capital. For instance, the value-creating potential of resources can be undermined or nullified through laws and regulations, budget cuts and policy changes that impact on available resources, cash for spending on training and retaining staff, research for organisational learning, policy and laws toward privatisation or deregulation and so forth.

R-A theory considers resources as tangible and intangible entities, which are both heterogeneous and imperfectly mobile among firms and enable the firm to produce efficiently and/or effectively a valued offering to some market segment or segments (Hughes \& Morgan, 2007; Hunt \& Morgan, 1995). Resources are imperfectly mobile if they cannot be traded, thus, they can become a source of sustained advantage (Peteraf, 1993). Hence, the organisation is perceived as a unique collection of idiosyncratic resources and capabilities (Hughes \& Morgan, 2007, 2008; Hunt, 2000; Grant, 1996). Within this theory, competitive advantage is considered to be rooted inside a firm, in assets that are valuable and inimitable. Therefore, an organisation's resources and management's abilities to marshal these assets to produce superior performance determine competitive advantage (Seggie \& Griffith, 2007; Hughes \& Morgan, 2007; Russo \& Fouts, 1997). Though, a firm’s resources 
can only be considered valuable when positioned in the external environment. Thus, for a firm's resources to become valuable, Barney (2001) argues that they must satisfy at least two conditions: firstly, they must enable the firm to exploit opportunities and/or neutralise threats in the competitive environment; and secondly, only a small number of firms in a particular competitive environment possess these resources (Lado \& Wilson, 1994).

In a comprehensive overview of R-A theory, Hunt (2000) and Hughes and Morgan (2007) identify several forms of capital including human, informational, relational, and organisational capital and recognise that there are numerous resources and capabilities which may be considered as capital. However, they state that not all forms of capital meet R-A theory prescriptions and therefore are not strategic as these must be significantly heterogeneous and imperfectly mobile between organisations and contribute to developing something of value to customers. That is, they must be strategically exploitable by the service provider to create value-creating services. Hughes and Morgan (2007) propose a multi-dimensional construct described as 'strategic capital', which can be manifested in organisations through intangibles comprising (though not exclusively) of strategy commitment, strategy implementation support, strategy implementation effectiveness, and organisational learning. The selected dimensions reflect human, informational, and organisational dimensions of capital and are strategic in nature as they are suggested to meet the necessary theory prescriptions of heterogeneity, immobility, and value (Hughes \& Morgan, 2007) and are intangible in nature and thus difficult for competitors to erode as bases for advantage and superior performance (Hunt, 2000). Thus, the source of sustainable competitive advantage can ultimately be attributed to the ownership of strategic capital (Lu \& Yang, 2010) and leveraging comparative advantages in strategic capital 
to create superior performance and competitive advantage (Griffith et al., 2010; Hunt \& Morgan, 1995).

The strategic capital construct is applied in relation to business strategy, which is concerned with deploying organisational resources to accomplish service-oriented goals (Day, 1999). This refers to desirable goals that the organisation seeks to achieve, for example, acquiring new customers, customer satisfaction, creating superior services and providing customer value. Ultimately, business strategy is concerned with the optimisation of strategic capital through the leveraging and deployment of the intangible strategic resources comprising the strategic capital construct so that it may compete in its chosen markets to achieve service-oriented goals (Day, 1999). Only when deployed through strategy does strategic capital provide the potential to develop advantage (Griffith et al., 2010; Seggie \& Griffith, 2007; Hunt, 2000).

In studies based on the private sector, internal resources have been identified as an important strategic approach (Pablo et al., 2007); moreover, strategic capital has been identified as critical to realising competitive advantage (Griffith et al., 2010; Hughes \& Morgan, 2007, 2008). While the traditional approach to resource-based research is to identify a set of resources and examine their performance effect (Hughes \& Morgan, 2007, 2008), R -A theory emphasises resource deployment over mere resource possession in the relationship between strategic capital and performance. In effect, any resource or form of capital that cannot be exploited by the service provider in strategy to create better and value-creating services is not strategic.

The purpose of examining the role of strategic capital is an attempt to expand the literature on strategic capital from the private to the public sector. Studies have yet 
to empirically demonstrate the effects of strategic capital on performance in public leisure organisations. This absence is a significant gap in the literature and is echoed by Pablo et al. (2007, p. 688) who state that 'we do not know how public sector organisations attempt to use their internal resources to improve organisational performance'. Research investigations into this would appear critical given the financial and budgetary constraints such public organisations are under. This research seeks to confront this issue.

\section{Internal and external public leisure provision}

At its most simple, the public sector comprises the activity of organisations that belong to the state or government (Lane, 2000). However, this conceptualisation is too simplistic to reflect the dynamic relationships that take place within the public sector. Continual restructuring of the public sector in England over the last twenty years, has promoted partnership working and external networks (Ferlie, Hartley, \& Martin, 2003). A central theme underpinning this transformation concerns competition from the private sector, in the provision of leisure services, and a reduction in public resources to provide them (Yorke, 1984). The ability of public services to respond effectively to changing market needs is imperative to effective provision. With growing expectations, successive generations of better-educated service users are turning from merely grateful acceptance of public services to knowledgeable customers intolerant of poor quality services that poorly fit their needs (Arie, 2000). For this reason, local governments are increasingly held accountable by the electorate for the performance of public organisations (Skelcher, 1992). The public sector has subsequently been charged with learning from private sector models to improve 
public sector provision (Friend, 2006). Such reform practices have been concerned with the internal and external operating environments of public service organisations and the transference of traditional government functions to a variety of organisations which are now responsible for the provision of public services (Fenwick \& McMillan, 2005). The externalisation of public services reflects the view that local government will achieve more for their communities, and service users if they develop a positive approach to working with suitable external partners (Simmons, 2004).

Internal service providers are the traditional vehicle for managing public services and still dominate public leisure provision in England. Within internal service provision, local government take full responsibility for income, expenditure, pricing and programming, and is accountable for all risks involved. However, local government re-organisation in 1994/1995 meant that resources previously available to leisure came under substantial pressure from the high costs of core services, such as education; thus, resources were transferred from non-core services, such as leisure, to fund budget deficits elsewhere (Reid, 2003). Due to increasing financial pressures on public leisure services, local governments are moving away from internal service providers, towards external management arrangements. External service providers are a response from local government to a changing environment, particularly in resisting financial pressures. In exchange for a lengthy management contract, an external agent manages the facility that provides the service. In turn, local government enters into a performance-management contract, where the voluntary or private sector manages the service as an agent of the local government.

In times of decreasing financial resources and governmental budgetary constraints to discretionary services such as leisure, there are assumed inequalities in strategic capital endowments between internal and external service providers, that is, 
those key inputs into strategy that determine the ability of organisations to compete effectively, and realise strategic outcomes (cf. Hughes \& Morgan, 2007, 2008). It is therefore important that in examining the effects of strategic capital on performance in the public leisure sector, a comparison of strategic capital endowments and business performance is made between internal and external service providers.

\section{Research model and hypotheses}

This study is a response to deficiencies in the public management literature, which provides few studies into whether the utilisation and deployment of strategic capital can improve service provision and hence, performance. The intended contributions of this study are threefold. Firstly, an attempt is made to establish which dimensions of the strategic capital construct confer performance benefits. Secondly, this study seeks to contribute to the increasing R-A literature by adopting this theory in an untested context. Thirdly, this study seeks to uncover any significant differences in strategic capital endowments and business performance, between internal and external leisure providers.

Since there is strong empirical support of a positive association between the individual dimensions of strategic capital and performance from the private sector (Hughes and Morgan, 2007, 2008; Noble \& Mokwa, 1999; Menon, Bharadwaj, Adidam, \& Edison, 1999; Baker \& Sinkula, 1999; Wooldridge \& Floyd, 1990), it is important to examine whether these relationships are evident in the public sector and address the issues highlighted by Pablo et al. (2007) of how internal capital can be employed to improve public service provision and performance. We provide an overview of the hypothesised relationships between strategic capital and performance 
on the basis of private sector evidence. To theorise otherwise would be counter to existing theory. We suggest that there is no need for a fundamental redefinition of strategic capital. Rather there is simply a need to reflect the specific context and characteristics of public services (Laing, 2003). This is underpinned by the contention that:

‘...there are very few inherently public services, as evidenced by the creeping privatisation of many such public services, raising the question of whether in fact many public services can be viewed as fundamentally different or unique’ (Laing, 2003, p. 430).

Under R-A theory, the role of management is to recognise, understand, create, select, implement and modify strategies (Seggie \& Griffith, 2007). Further, and as stated previously, the main forms of capital that form strategic capital are human, informational, relational and organisational capital. Relational capital is defined as the leisure provider's relationships with customers, suppliers, competitors, government agencies and so forth (Hunt, 2000). For the purposes of this study we do not consider relational capital elements as these are catered for in study design as we are examining public sector leisure providers that invariably are subject to government agencies and policy considerations. Following Hunt (2000) and Hughes and Morgan (2007), we consider four elements that relate to human, informational and organisational dimensions of strategic capital: strategy commitment, implementation support and effectiveness and organisational learning. All of these are within the control of public leisure providers and are not necessarily subject to external constraints such as fiscal and budgetary pressures. Additionally, such elements of strategic capital are important in public organisations in effectively understanding what customers demand as service and why they would use public leisure providers 
(i.e., organisational learning); having employees and management committed to the necessary strategy; and being able to implement that strategy, which is typically an area in which public organisations suffer.

Strategy commitment is defined as the extent to which a manager comprehends and supports the goals and objectives of the chosen service strategy (Hughes \& Morgan, 2007, 2008; Noble \& Mokwa, 1999). Strategy commitment is an intangible resource and a human element of strategic capital (Hughes \& Morgan, 2007; Hunt, 2000). Strategy commitment varies between organisations and increases when shared by a collective; implying that it is both heterogeneous and imperfectly mobile (Hughes \& Morgan, 2007). Understanding and being committed to the goals of the strategy should be of benefit in achieving the goals of that strategy. Subsequently, developing commitment to the service strategy builds support for the strategy, provides impetus to its development and assists in limiting resistance to strategy, and has been associated with superior performance (Hughes \& Morgan, 2008; Wooldridge \& Floyd, 1990). Furthermore, Boshoff and Mels (2000) argue that nurturing commitment can enhance organisational effectiveness, which they argue ought to lead to desirable outcomes such as enhanced profitability and an increased probability of long-term survival.

We suspect that strategy commitment is a precondition for achieving superior business performance. An absence of commitment to strategy implies an element of resistance or non-belief in the strategy such that realising the strategy is then compromised (cf. Hughes \& Morgan, 2007). Any compromise in delivering a strategy invariably leads to a misfit between strategy and what the organisation is actually doing and often leads to a failure of strategy and collapse of business performance. As Hughes and Morgan (2007) found, unsuccessful (poor performing) strategists suffered 
from lower levels of commitment relative to higher performing rivals and since competitive advantage is achievable through commitment to the strategy, it would be expected that strategy commitment on behalf of the public leisure provider will accrue service performance benefits.

$\mathbf{H}_{\mathbf{1}}$ : Strategy commitment will be positively associated with performance for public leisure providers.

Strategy implementation support refers to the resource structure of the organisation being aligned to the chosen strategy and the subsequent allocation of necessary resources for implementation to occur (Hughes \& Morgan, 2008). Support resources of money, time, people and commitment suggested by Menon et al. (1999) to be key elements of successful strategy-making. Consequently, this element of strategic capital is critical to the firm. Competing organisations possess unequal levels of resources for implementation support, and thus, are sources of heterogeneity between organisations (Hughes \& Morgan, 2007). Insufficient implementation support may constrain the ability of an organisation to both implement the strategy successfully and compete along the chosen service strategy (Menon et al., 1999). Menon et al. (1999) suggest that without exception, implementation support is a central element of the strategy development process for realising success. As evidence, Hughes and Morgan (2007) found that poor performing organisations were endowed with significantly lower levels of implementation support resources relative to higher performing rivals whilst Menon et al. (1999) concluded from interviews with managers that strategies often failed due to a lack of necessary resources. Implementation support, then, is a necessity in pursuing business strategy, which 
subsequently influences organisational performance. Therefore, comparative advantages in support endowments would be expected to result in a competitive advantage relative to those rivals at a comparative disadvantage in terms of support resources, and accordingly, this would enable the organisation to efficiently and effectively produce services that customers value.

Organisations occupying positions of competitive advantage can continue to do so if they continually reinvest in the support endowments that produced the competitive advantage and superior business performance (Hunt \& Lambe, 2000). Thus, we contend that a comparative advantage in resource endowments specifically for the allocation of necessary resources for implementation of the strategy to occur will result in business performance benefits for public leisure providers.

$\mathbf{H}_{2}$ : Strategy implementation support will be positively associated with performance for public leisure providers.

Strategy formation and implementation must be simultaneously integrated creating the personal and organisational awareness, understanding, acceptance and commitment required to implement strategies effectively (Ireland, Hoskisson, \& Hitt, 2009; Quinn, 1980). Noble and Mokwa (1999) suggest that implementation pervades strategic performance and is a critical link between the formulation of strategies and the achievement of superior performance.

Therefore, implementation is viewed as a resource as Barney (2001, p. 54) states 'the ability to implement strategies is, itself, a resource that can be a source of sustained strategic advantage'. The ability to implement effectively is an important and complex capability for organisations which is developed over time from the skills 
and accumulated knowledge of the organisation enabling it to make use of its assets to achieve desired goals (Hughes \& Morgan, 2007). Under R-A theory, effective implementation is seen as a critical capability and organisational element of strategic capital (Hunt, 2000) that enables management to implement and modify strategies as necessary (Seggie \& Griffith, 2007). The ability to implement strategy effectively is not universal amongst organisations; cannot be easily transferred; and, may provide means to a competitive advantage by rapidly redeploying resources and strategy to pursue market opportunities or meet customer needs faster than competitors (Hughes \& Morgan, 2007; Barney, 2001). These managerial actions are critical in achieving the desired organisational goals. Effective implementation is therefore seen as a key component for achieving strategy effectiveness through achieving strategic goals, and is subsequently associated with greater performance levels (Noble \& Mokwa, 1999) and advantage (Hughes \& Morgan, 2007, 2008; Barney, 2001). Indeed, low performing organisations were found by Hughes and Morgan (2007) to be significantly worse at implementation relative to all other rivals.

Ultimately, an inability to effectively implement the service strategy is likely to reduce the leisure provider's capacity to deliver superior value (Hughes \& Morgan, 2007) and performance (Barney, 2001). As established, without the capability to implement strategy effectively the leisure provider cannot seek to reach its desired goals or business performance objectives as its basis for competing and attracting facility users is compromised. We suspect then that those leisure providers that are more effective at implementation will perform better than rivals without such a base in their strategic capital bundle. Therefore, without the ability to implement a chosen strategy effectively, we suspect that public leisure providers would not realise business performance goals: 
$\mathbf{H}_{3}$ : Strategy implementation effectiveness will be positively associated with performance for public leisure providers.

Knowledge (being often intangible and tacit) has long been a central tenet of the resource-based and knowledge-based views of the firm (Grant, 1996) but Hughes and Morgan (2007) identify an integral component of R-A theory is the ability of organisations to employ knowledge-based resources to learn in order to develop a service offering of superior value to customers. That is, organisational learning.

Research into organisational learning focuses on the acquisition and creation of organisational knowledge (Grant, 1996). At its most basic level, organisational learning is the development of new knowledge or insights that have the potential to direct behaviour (Slater \& Narver, 1995) and as such, provides a means to improve resource deployment and as a natural consequence, the provision of service. The ability to apply capabilities in the form of inimitable knowledge resources is vital to achieve advantage (Grant, 1996), and research supports that organisational learning leads to competitive advantage and superior performance (Baker \& Sinkula, 1999).

Within R-A theory, organisational learning is a critical informational and knowledge-based element of strategic capital (Griffith et al., 2010; Hunt, 2000). Informational capital is the firm's knowledge relating to its products, processes, customers, competitors and resources (Griffith et al., 2010; Hughes \& Morgan, 2007; Hunt, 2000). Such capital then derives from organisational learning investments in information, marketing research and competitive intelligence (Hunt, 2000). Accordingly, it is expected that organisational learning would benefit performance in 
increasing the ability of the firm to be responsive to customers and external environmental changes (Griffith et al., 2010).

Under R-A theory it is assumed that different organisations learn and use information to varying degrees of intensity, thus it would be expected that higher performing organisations exhibit greater levels of organisational learning in comparison with lower performing counterparts, as an organisation's learning capabilities can help to explain persistent differences among organisations in profiting from externally acquired knowledge (Lichtenthaler, 2009). Hughes and Morgan (2007) demonstrate this as low performing firms were found to be significantly worse at organisational learning than high performing rivals and as such this element of strategic capital contributes much to strategy success. Therefore, the ability to generate critical learning points that refine organisation activities now and into the future can generate significant benefits in the form of defendable competitive advantages and sustainably superior performance (Lichtenthaler, 2009; Cockburn, Henderson, \& Stern, 2000).

Organisations learn from operating in their respective marketplaces whilst competing and through this can become aware of the relative resource endowments of rivals, their strategies and means to provide value to customers beyond their competitors (Hunt, 2000). Learning, as an element of strategic capital, can then enable the organisation to degrade rivals’ comparative advantages and deliver stronger positions of advantage (comparative and competitive) for the organisation (Hughes \& Morgan, 2007). Regardless of public or private sector, organisations need to learn and establish positions of advantage between them and their rivals in order to succeed in attracting custom and improving performance. We suspect, then, that public leisure 
service providers will be able to generate better service provision through organisational learning and thus enhance performance.

$\mathbf{H}_{4}$ : Organisational learning will be positively associated with performance for public leisure providers.

Further to these hypotheses, we expect that the superior performing provider, whether internal or external, will be endowed with significantly greater levels of strategic capital. That is, the relative levels of strategy commitment, strategy implementation support, strategy implementation effectiveness, and learning will be significantly greater in the higher performing provider than in their lower performing counterpart.

\section{Research method}

This study adapts perceptual measures used by Hughes and Morgan (2007) to capture the strategic capital dimensions, which include measures of strategic commitment and implementation effectiveness, informed by Noble and Mokwa (1999); measures of implementation support, informed by Menon et al. (1999); and measures of organisational learning, inspired by Sherman, Souder, and Jenssen (2000) and Hult, Ferrell, and Hurley (2002). The items capturing the dependent variable of business performance were adapted from Delaney and Huselid (1996) and encompass perceptual measures regarding new customers, profitability, market share and marketing. Research has found measures of perceived performance to correlate

positively with objective measures of performance (Krohmer, Homburg, \& Workman, 
2002; Delaney \& Huselid, 1996). The inclusion of perceptual measures enables an analysis of the performance of public leisure service providers as specific objective data for these organisations is largely unavailable (Krohmer et al., 2002). Performance measures such as profitability and market share are widely used in extant strategy literature. However, the items adopted place emphasis on financial performance, specifically new customer sales, profitability, market share and marketing which refers to the ability to refine organisation activities now and into the future which can generate significant benefits in the form of sustainably superior performance (Lichtenthaler, 2009; Cockburn et al., 2000). Therefore, since the items focus on economic outcomes (Delaney and Huselid, 1996) it was deemed appropriate to combine the four measures into a single dependent variable termed business performance. A 7-point Likert-type scale was adopted for all items, to improve reliability and for reasons of ease of response and administration. Strategic capital scales were ranked from (1) strongly disagree to (7) strongly agree. Performance measures were scaled as (1) very poor to (7) excellent, when comparing performance over the past 3 years to that of other competing leisure facilities. The precise wording of measurement items pertaining to measures of strategic capital and business performance are presented in Appendix A, along with the properties of these measurement items as derived through confirmatory factor analysis.

Using a mail survey approach, this study targeted the entire population of local government-owned public leisure facilities in England. This population was sourced from The Leisure Database (TLDCi). In total, 1,060 questionnaires were sent to public leisure facility managers nationally. Public leisure facility managers were deemed key informants because such individuals have the knowledge necessary to measure the variables under investigation and would have most knowledge on 
strategic capital and the performance of the facility. The survey instrument follows the recommendations, directions and principles of good questionnaire development practice set forth by Dillman (2007). This involved pre-notification; mailing of a full questionnaire pack; first reminder; and second reminder consisting of a full questionnaire pack, and includes recommendations regarding cover letter, return postage, anonymity, lack of explicit deadlines and university sponsorship.

In total, an overall useable response rate of 26 per cent (280) was achieved, with a strong representation of both internal (152) and external (128) public leisure providers. A single source self-report questionnaire was used to generate data in this study and a drawback of this approach is that common method bias may underlie the data. In developing the instrument, the directions of Spector and Brannick (1995) for limiting this bias were followed: measurement scales were placed in random order; non-idealised responses and wording neutrality were adopted; questionnaire length was reduced (3 pages); and detailed instruction for completion were provided. Statistical tests for common method bias through Harman’s one-factor approach, using a single factor analysis, revealed no evidence of common method bias.

Content and face validity was established on the basis of expert judgement. Content validity was determined by distributing the questionnaire to several academics that had substantial knowledge of the literature from which the constructs were derived. Consequently, being able to comment on the degree to which the measures used capture the aforementioned constructs. Similarly, distributing the questionnaire to several public leisure managers, with the objective to ensure that the measures employed were appropriately worded and understood by the respondents, assessed face validity. To ensure the accuracy of responses, feedback given by academics and public leisure managers on the measures employed was used to 
enhance and modify the research questionnaire. Therefore, the content and face validity of the measures contained within the questionnaire was established.

Measurement items were subjected to confirmatory factor analysis through LISREL 8.8. The model fits the data well as demonstrated by the model fit statistics: $\chi^{2}=213.03 ;$ degrees of freedom $=109 ; \chi^{2} / \mathrm{df}=1.95$; Root Mean Square Error of Approximation $=.06$; Comparative Fit Index $=.98$; Incremental Fit Index $=.98$; NonNormed Fit Index $=.98$; Goodness of Fit Index $=.91$. All fit indices are well within accepted thresholds (Hu \& Bentler, 1999; Bollen, 1989). To gauge the degree of internal consistency of the strategic capital and business performance scales, the composite reliability (CR) and average variance extracted (AVE) were calculated. All were above acceptable thresholds and are shown in Table 1 . To demonstrate discriminant validity, the square root of each AVE must exceed all correlations between the constructs under examination. As is shown in Table 1, all values exceed the correlations and so we claim discriminant validity (Hughes \& Morgan, 2008).

\section{Analysis and results}

Correlation analysis is utilised as a means to confirm the validity of the research hypotheses. The purpose of this analysis is to provide an early indication of the kind of association between study variables and to examine the accuracy of the research hypotheses.

[Table 1 near here] 
The analysis clearly demonstrates significant positive correlations between the study variables. However, correlation analysis is employed as a precursor to a more extensive hypothesis testing through structural equation modelling (SEM) analysis. SEM analysis is utilised to provide a robust assessment of the relationship between strategic capital and business performance in the public leisure sector. Table 2 presents the results from this analysis.

\section{[Table 2 near here]}

With reference to Table 2, the Squared Multiple Correlations for Reduced Form is equivalent to $\mathrm{R}^{2}$ under regression and reveals that the relationship between dimensions of strategic capital and performance explains $48 \%$ of business performance. Examination of the findings presents a clear relationship between the independent dimensions of strategic capital and business performance. From a theoretical and literature point of view, the power of strategy implementation effectiveness in conferring positive performance is supported as it is shown to have business performance benefits for public leisure providers $(.66 ; p \leq .01)$, thus

confirming $\mathrm{H}_{3}$. Organisational learning has a mild positive influence on performance at the $10 \%$ significance level $(.09 ; t=1.28)$. However, there are no significant performance implications for strategy commitment or implementation support.

Despite these findings, R-A theory implies that successful organisations are endowed with significantly greater levels of all dimensions of strategic capital (Hughes \& Morgan, 2007). To examine the hypotheses further then we split our sample between high performers $($ mean $=5.17)$ and low performers $($ mean $=3.34)$ and conducted an analysis of variance (ANOVA) and independent t-tests (Table 3). It 
is clear from the results that high performers are endowed with significantly greater levels of all strategic capital dimensions and so speak to the importance of strategic capital for public leisure providers. These results embellish the SEM results in demonstrating that whilst implementation effectiveness has a strong impact, all other dimensions of strategic capital should not be ignored or devalued as all are important for high performance.

\section{[Table 3 near here]}

The next stage of analysis identifies if there is any significant variation in strategic capital endowments and business performance between internal and external providers. ANOVA is utilised to examine for group differences on each dimension of strategic capital and performance. ANOVA can inform researchers of significant differences between the means of two groups, allowing conclusions to be drawn regarding whether a set of groups differ significantly.

\section{[Table 4 near here]}

Table 4 identifies several significant differences between internal and external service providers with respect to strategic capital. External providers are shown to have consistently greater levels of strategic capital relative to internal providers. In addition, external providers have far superior business performance when compared to internal providers, indicating that strategic capital facilitates stronger business performance. Strategy implementation support was shown to have the greatest significant disparity of the strategic capital dimensions between the two groups, 
indicating that internal providers struggle to execute their strategies and is consistent with what one might expect given that the externalisation of the service is suggested to unlock hidden potential leading to increased revenue, investment and business sustainability (Reid, 2003). The results show, however, that organisational learning is not significantly greater for external providers suggesting that in the public leisure sector, there is no difference between internally or externally managed providers and learning may not contribute to performance improvements/differences.

\section{Discussion and implications}

Our findings confirm that strategic capital does have a direct positive performance relationship in the public leisure sector through implementation effectiveness and organisational learning. It is apparent that effective implementation of the strategy is a key component of achieving strategy effectiveness through achieving service-oriented goals, since it is associated with greater business performance. The ability to effectively implement the chosen strategy arguably enables leisure providers to deploy its strategic capital base and exploit comparative advantages. The ability to implement effectively is distinct between organisations and cannot be easily transferred (Hughes \& Morgan, 2007), thus making this dimension of strategic capital a key differentiating factor for economic survival in the public leisure sector. Hence, it is suggested that public leisure providers may be able to increase their business performance through the effective implementation of their business strategy and developing a capability in this. This finding suggests that the ability to implement strategies is, itself, a resource that can be a source of sustained advantage in public leisure management as witnessed in the private sector (Barney, 2001). Further, 
exploiting resources to effectively implement strategy means that the service provider is able to compete using its chosen methods (Hughes \& Morgan, 2007). The strategic capital dimensions of strategy commitment and strategy implementation support, however, do not have a direct relationship with business performance in the public leisure sector. However, this is not to say that these strategic capital dimensions have no relationship with performance at all, as shown from the ANOVA analysis (Table 3) which demonstrates a positive, significant difference between each dimension and performance when providers are split by high and low performers. Although no direct relationships between the aforementioned dimensions of strategic capital and performance has been established under SEM, it is evident from the between groups analysis that a comparative advantage in strategic capital endowments is important for realising business performance goals.

We suggested during hypothesising that strategic capital would be a differentiating factor between the higher and lower performing service provider, such that the higher performing provider would be endowed with greater levels of strategic capital. Our findings confirm this view as high performing providers were endowed with significantly greater levels of strategic capital relative to low performers. Further analysis between internal and external leisure providers show that external providers outperform internal leisure providers and are endowed with consistently greater levels of strategic capital relative to internal leisure providers. Internal and external leisure providers are shown to possess significantly unequal levels of resource endowments which contribute to explaining performance differences between these groups. Specifically, strategy commitment, implementation support, and implementation effectiveness were shown to vary significantly between the two groups whereby external leisure providers exhibit significantly greater mean levels of these resources 
relative to internal leisure providers. Consistent with R-A theory and evidence from the private sector, it can be said that successful strategists are endowed with greater strategic capital in the public leisure sector. Lower performing internal leisure providers were particularly poor at implementation support, indicated by the greatest significant disparity between groups, and implementation effectiveness, which is shown to have a direct relationship with superior business performance. This therefore implies important public policy implications. Should government invest in internally managed facilities or introduce external management, which, prima facie, appears to be a more effective means of managing public leisure providers.

There is, however, somewhat of an inconsistency between the findings and extant literature. In the private sector, successful strategists are endowed with greater learning capabilities relative to rivals, and as such learning is considered to play a key role in achieving superior strategy performance (Hughes \& Morgan, 2007; Baker \& Sinkula, 1999). On the basis of the findings and consistent with Fenwick and McMillan (2005), it is suggested that organisational learning in the public leisure sector is not necessarily delivered more effectively through external service providers, since there is no significant difference in the mean values presented for organisational learning between service providers. Therefore, the assumption that external vehicles for service delivery are necessarily positive mechanisms for inter-organisational learning may be misplaced (Fenwick \& McMillan, 2005). Further, whilst we find a positive relationship between learning and performance, it is only at the $10 \%$ significance level. Existing research suggests that learning should have a strong effect. Whilst theoretically it would be expected, and we did find learning to be important in high performing firms (Table 3), we suggest that more research is needed into organisational learning in the public context. 
Nevertheless, external leisure providers are endowed with significantly greater levels of strategic capital (across all dimensions) relative to internal leisure providers (Table 4). External leisure providers are therefore in a far better position to realise performance goals given their greater capabilities to implement chosen strategies and this is borne out in the differences in performance between the two providers. By implication, leisure service provision needs to be considered carefully by local government to determine the best mode of management that can make most effective use of scarce strategic capital. On the basis of our findings, external leisure provision is a superior method. Thus in response to the concerns of Pablo et al. (2007), strategic capital can be employed to improve service provision and performance in public leisure providers and this is best capitalised upon through external management.

\section{Limitations and further research}

This study was not without its limitations. First, this study was based on a crosssectional design, and does not allow absolute causality to be asserted from the data. Second, this study sampled public leisure providers in England. As government structures, service delivery, and resource allocation systems differ between other public services, sectors and countries, caution must be exercised against generalising the results to populations markedly different to that examined here. Third, perceptual measures of business performance are relied upon as access to objective business performance data was largely unavailable and thus could not be employed. We acknowledge this as a limitation. Fourth, though strategy implementation effectiveness is shown to pervade business performance, it is acknowledged that possible interactions may exist among other dimensions of strategic capital and 
implementation effectiveness, for example, different forms of commitment have been considered as antecedents to implementation while the importance of championing in implementation has been discussed in a range of literatures (Noble \& Mokwa, 1999). Examining for such interactions is beyond the scope of this study, as we look for significant relationships between strategic capital dimensions and business performance and significant differences between providers along these dimensions and performance.

Noble and Mokwa (1999) contend that understanding of how a given strategy fits in the overall vision of an organisation influences managers' commitment to see that strategy successfully implemented. Building on the limitations of this study, we recognise that little is known about the performance implications of fitting the strategic resource base with the strategy of public service organisations. It has been shown that the strategic resources which comprise the strategic capital construct are critical to business performance in the public leisure sector. Developing the notion of fit, Hughes and Morgan (2008) suggest that the chosen strategy should fit the organisation's unique bundle of strategic capital endowments to its environment for improved competitive outcomes. We suggest that future research should examine different strategic capital elements and address whether greater fit between the strategic capital base of public organisations and the chosen strategy encourages superior performance.

By reflecting on our findings we posit that strategies in the public leisure sector result in superior business performance returns when they are implemented successfully. Moreover, we find that between groups, external leisure providers are endowed with significantly greater levels of strategic capital and realise superior business performance returns relative to internal leisure providers. We suggest that 
future research seeks to explore the implications of the public-private dichotomy in the provision of other public services and present further evidence as to which mode of provision can best deliver service-oriented goals.

\section{References}

Arie, T. (2000). What's coming next in services?. Hong Kong Journal of Psychiatry, 10(2), 8-10.

Baker, W.E., \& Sinkula, J.M. (1999). The synergistic effect of market orientation and learning orientation on organizational performance. Journal of the Academy of Marketing Science, 27(4), 411-427.

Barney, J.B. (2001). Is the resource-based view a useful perspective for strategic management research? Yes. The Academy of Management Review, 26(1), 41-56.

Boshoff, C., \& Mels, G. (2000). The impact of multiple commitments on intentions to resign: an empirical assessment. British Journal f Management, 11(3), $255-272$.

Boyne, G.A., \& Walker, R.M. (2004). Strategy content and public service organisations. Journal of Public Administration and Research and Theory, 14(2), 231-252.

Clohesy, W.W. (2003). Fund-raising and the articulation of common goods. Nonprofit and Voluntary Sector Quarterly, 32(1), 128-140.

Cockburn, I., Henderson, R., \& Stern, S. (2000). Untangling the origins of competitive advantage. Strategic Management Journal, 21, 1123-1146. 
Day, G.S. (1999). Market-driven strategy, processes for creating value. New York: Free Press.

Delaney, J.T., \& Huselid, M.A. (1996). The impact of human resource management practices on perceptions of organisational performance. Academy of Management Journal, 39(4), 949-969.

Dillman, D.A. (2007). Mail and internet surveys: the tailored design method. New Jersey: John Wiley \& Sons.

Fenwick, J., \& McMillan, J. (2005). Organisational learning and public sector management: an alternative view. Public Policy and Administration, 20(3), 42-55.

Ferlie, E., Hartley, J., \& Martin, S. (2003). Changing public service organisations: current perspectives and future prospects. British Journal of Management, 14(1), 1-14.

Friend, J. (2006). Partnership meets politics: managing within the maze. International Journal of Public Sector Management, 19(3), 261-277.

Grant, R.M. (1996). Toward a knowledge-based theory of the firm. Strategic Management Journal, 17(winter special issue), 109-122.

Griffith, D.A., Yalcinkaya, G., \& Calantone, R.J. (2010). Do marketing capabilities consistently mediate effects of firm intangible capital on performance across institutional environments?. Journal of World Business, 45, 217-227.

Hughes, P., \& Morgan, R.E. (2007). A resource-advantage perspective of product-market strategy performance and strategic capital in high technology firms. Industrial Marketing Management, 36(4), 503-517. 
Hughes, P., \& Morgan, R.E. (2008). Fitting strategic resources with productmarket strategy: performance implications. Journal of Business Research, 61(4), 323-331.

Hult, G.T., Ferrell, O.C., \& Hurley, R.F. (2002). Global organisational learning effects on cycle time performance. Journal of Business Research, 55(5), 377-387

Hunt, S.D. (2000). A general theory of competition. Thousand Oaks, CA: Sage.

Hunt, S.D., \& Lambe, C.J. (2000). Marketing's contribution to business strategy: market orientation, relationship marketing and resourceadvantage theory. International Journal of Management Reviews, 2(1), 17-43.

Ireland, R.D., Hoskisson, R.E., \& Hitt, M.A. (2009). The management of strategy. Canada: South-Western Cengage Learning.

Krohmer, H., Homburg, C., \& Workman, J.P. (2002). Should marketing be crossfunctional? conceptual development and international empirical evidence. Journal of Business Research, 55(6), 451-465.

Lado, A.A., \& Wilson, M.C. (1994). Human resource systems and sustained competitive advantage: a competency-based perspective. The Academy of Management Review, 19(4), 699-727.

Laing, A. (2003). Marketing in the public sector: towards a typology of public services. Marketing Theory, 3(4), 427-445.

Lane, J. (2000). New public management. London: Routledge. 
Lichtenthaler, I. (2009). Absorptive capacity, environmental turbulence, and the complementarity of organisational learning processes. Academy of Management Journal, 52, 822-846.

Lu, C.S., \& Yang, C.C. (2010). Logistics service capabilities and firm performance of international distribution center operators. The Service Industries Journal, 30(2), 281-298.

Menon, A., Bharadwaj, S.G., Adidam, P.T., \& Edison, S.W. (1999).

Antecedents and consequences of marketing strategy making: a model and a test. Journal of Marketing, 63(2), 18-40.

Noble, C.H., \& Mokwa, M.P. (1999). Implementing marketing strategies: developing and testing a managerial theory. Journal of Marketing, 63(4), 57-73.

Nunnally, J.C. (1978). Psychometric Theory. New York: McGraw-Hill.

Pablo, A.L., Reay, T., Dewald, J.R., \& Casebeer, A.L. (2007). Identifying, enabling and managing dynamic capabilities in the public sector. Journal of Management Studies, 44(5), 687-708.

Peteraf, M.A. (1993) The cornerstones of competitive advantage: a resource-based view. Strategic Management Journal, 14(3), 179-191.

Quinn, J.B. (1980). Strategies for change: logical incrementalism. Illinois, USA: Irwin.

Reid, G. (2003). Charitable trusts: municipal leisure’s third way?. Managing Leisure, 8(4), 171-183.

Russo, M.V., \& Fouts, P.A. (1997). A resource-based perspective on corporate environmental performance and profitability. The Academy of Management Journal, 40(3), 534-559. 
Sanchez, R., Heene, A., \& Thomas, H. (1996). Dynamics of competence-based competition. New York: Elsevier.

Sherman, J.D., Souder, W.E., \& Jenssen, S.A. (2000). Differential effects of the primary forms of cross-functional integration on product development cycle time. Journal of Product Innovation Management, 17(4), 257-267.

Simmons, R. (2004). A trend to trust? the rise of new leisure trusts in the UK. Managing Leisure, 9(3), 159-177.

Slater, S.F., \& Narver, J.C. (1995). Market orientation and the learning organization. Journal of Marketing, 59(3), 63-74.

Skelcher, C. (1992). Improving quality of local public services. The Service Industries Journal, 12(4), 463-477.

Spector, P.E., \& Brannick, M.T. (1995). The nature and effects of method variance in organizational research. In C.L. Cooper, \& I.T. Robertson (Eds.), International Review of Industrial and Organizational Psychology 10 (pp. 249-274). Chichester: Wiley.

Wooldridge, B., \& Floyd, S.W. (1990). The strategy process, middle management involvement, and organizational performance. Strategic Management Journal, 11(3), 231-241.

Yorke, D. (1984). Local authorities and the marketing of leisure services. The Service Industries Journal, 4(3), 151-165. 


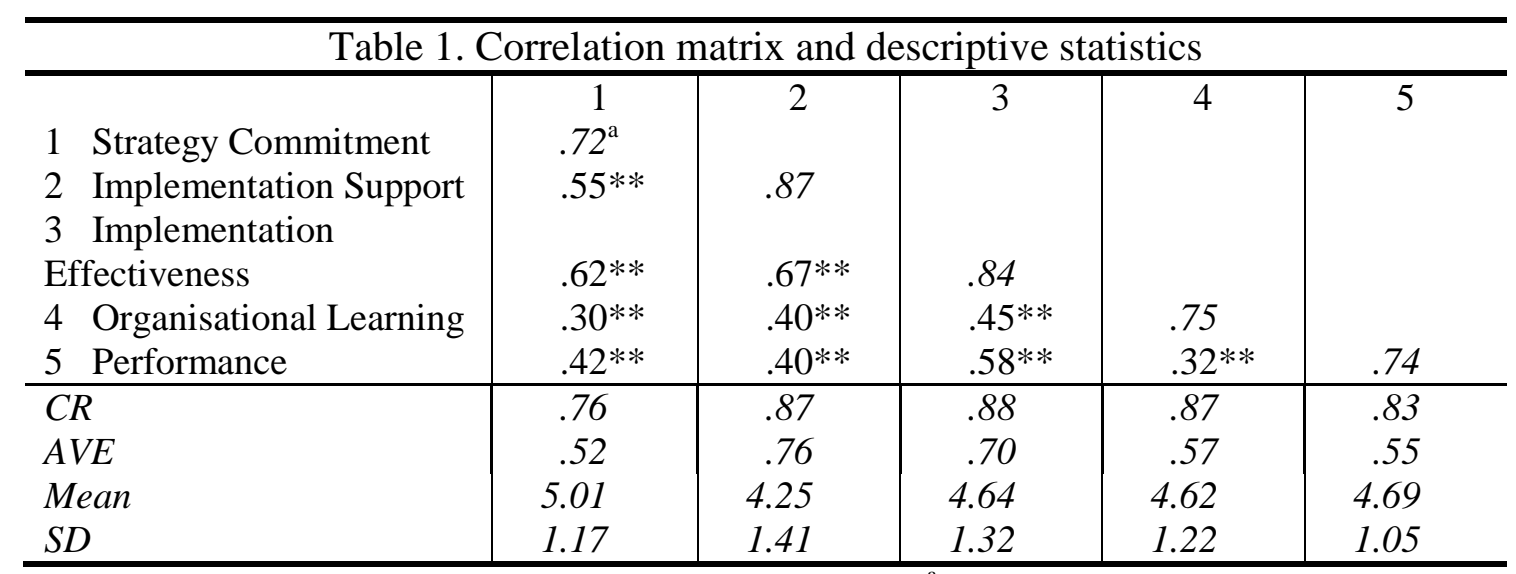

Notes: **. Correlation is significant at the 0.01 level (2-tailed). ${ }^{\mathrm{a}}$ Square root of AVE. 


\begin{tabular}{lccc}
\hline \multicolumn{2}{c}{ Table 2. Structural equation modelling analysis } \\
\hline $\begin{array}{c}\text { Independent } \\
\text { Variable }\end{array}$ & Hypothesis & $\begin{array}{c}\text { Standardised } \\
\text { Path Coefficient }\end{array}$ & t-value \\
Strategy Commitment & $\mathrm{H} 1$ & .08 & .72 \\
Implementation Support & $\mathrm{H} 2$ & -.11 & -1.05 \\
Implementation Effectiveness & $\mathrm{H} 3$ & .66 & $4.67^{* *}$ \\
Organisational Learning & $\mathrm{H} 4$ & .09 & $1.28^{*}$ \\
\hline \multicolumn{3}{l}{ Model Statistics } & 213.03 \\
$\chi^{2}$ & & 109 \\
$R M S E A$ & & & .06 \\
CFI & & .98 \\
IFI & & .98 \\
NNFI & & .98 \\
GFI & & .91 \\
Squared Multiple Correlations for Reduced Form $\left(R^{2}\right)$ & .48 \\
\hline
\end{tabular}

Notes: ${ }^{* *} p \leq 0.01 .{ }^{*} p \leq 0.10$. 


\begin{tabular}{lcccc}
\hline \multicolumn{4}{c}{ Table 3. ANOVA of strategic capital between performance groups } \\
\hline Strategic Capital & \multicolumn{2}{c}{$\begin{array}{c}\text { Performance Group } \\
\text { (Mean [SD]) }\end{array}$} & F-value & t-value \\
& $\begin{array}{c}\text { Low } \\
\text { Performers }\end{array}$ & $\begin{array}{c}\text { High } \\
\text { Performers }\end{array}$ & $\begin{array}{c}\text { Between } \\
\text { Groups }\end{array}$ & \\
\hline Strategy Commitment & $4.37(1.21)$ & $5.23(1.06)$ & $32.90^{* *}$ & $5.39^{* *}$ \\
Implementation Support & $3.42(1.39)$ & $4.52(1.29)$ & $36.66^{* *}$ & $5.86^{* *}$ \\
Implementation & & & & \\
Effectiveness & $3.68(1.37)$ & $4.96(1.11)$ & $62.36^{* *}$ & $7.88^{* *}$ \\
Organisational Learning & $4.04(1.37)$ & $4.81(1.09)$ & $22.30^{* *}$ & $4.72^{* *}$ \\
\hline
\end{tabular}

Notes: ${ }^{* *} p \leq 0.01$ 
Table 4. ANOVA of strategic capital and performance between approaches to provision

\begin{tabular}{lcccc}
\hline Strategic Capital & \multicolumn{2}{c}{$\begin{array}{c}\text { Approach to Provision } \\
\text { (Mean [SD]) }\end{array}$} & F-value & t-value \\
& Internal & External & $\begin{array}{c}\text { Between } \\
\text { Groups }\end{array}$ & \\
\hline Strategy Commitment & $4.82(1.20)$ & $5.23(1.10)$ & $8.70^{* *}$ & $2.97^{* *}$ \\
Implementation Support & $3.92(1.44)$ & $4.63(1.28)$ & $18.77^{* *}$ & $4.38^{* *}$ \\
Implementation & & & & \\
Effectiveness & $4.41(1.40)$ & $4.91(1.16)$ & $10.33^{* *}$ & $3.22^{* *}$ \\
Organisational Learning & $4.52(1.32)$ & $4.74(1.07)$ & 2.23 & 1.51 \\
Performance & $4.41(1.08)$ & $5.01(0.93)$ & $23.98^{* *}$ & $4.95^{* *}$ \\
\hline Notes: ${ }^{* *} p \leq 0.01$ & & & &
\end{tabular}




\begin{tabular}{|c|c|c|c|}
\hline \multicolumn{4}{|c|}{ Appendix A. Measurement item properties } \\
\hline Construct & Measurement Item & $\begin{array}{c}\text { Standardised } \\
\text { Factor } \\
\text { Loading } \\
\end{array}$ & $t$-values \\
\hline $\begin{array}{l}\text { Strategy } \\
\text { Commitment }\end{array}$ & $\begin{array}{l}\text { I don’t think the overall product-market } \\
\text { strategy is in the best interests of the facility } \\
\text { (R) } \\
\text { I believe the overall product-market strategy } \\
\text { is a great idea } \\
\text { I can't say that I support the overall product- } \\
\text { market strategy (R) }\end{array}$ & $\begin{array}{l}.68 \\
.75 \\
.72\end{array}$ & $\begin{array}{l}11.45 \\
12.94\end{array}$ \\
\hline $\begin{array}{l}\text { Implementation } \\
\text { Support }\end{array}$ & $\begin{array}{l}\text { The right resources are allocated to } \\
\text { implementation efforts for the overall product } \\
\text { market-strategy } \\
\text { The resource structure is now well aligned } \\
\text { with the overall product-market strategy }\end{array}$ & $\begin{array}{l}.89 \\
.86\end{array}$ & $\begin{array}{r}16.97 \\
16.14\end{array}$ \\
\hline $\begin{array}{l}\text { Implementation } \\
\text { Effectiveness }\end{array}$ & $\begin{array}{l}\text { I personally think the implementation of the } \\
\text { overall product-market strategy is considered } \\
\text { a success in the facility } \\
\text { The facility's implementation effort on the } \\
\text { overall product-market strategy is } \\
\text { disappointing (R) } \\
\text { The implementation of the overall product- } \\
\text { market strategy is generally considered a } \\
\text { great success in the facility }\end{array}$ & .76 & 14.18 \\
\hline $\begin{array}{l}\text { Organisational } \\
\text { Learning }\end{array}$ & $\begin{array}{l}\text { Meetings are frequently conducted to identify } \\
\text { what can be learned and subsequently } \\
\text { improved upon activities and events } \\
\text { We always audit unsuccessful product- } \\
\text { market strategy endeavours and communicate } \\
\text { the lessons learned } \\
\text { Lessons learned from past product-market } \\
\text { decisions are thoroughly shared and } \\
\text { discussed with others in the facility } \\
\text { We have specific mechanisms for sharing } \\
\text { lessons learned in the overall product-market } \\
\text { strategy process } \\
\text { Facility conversation keeps alive the lessons } \\
\text { learned from overall product-market strategy } \\
\text { history }\end{array}$ & .85 & 16.58 \\
\hline $\begin{array}{l}\text { Business } \\
\text { Performance }\end{array}$ & $\begin{array}{l}\text { Attracting new customers. } \\
\text { Marketing. } \\
\text { Profitability. } \\
\text { Market share. }\end{array}$ & $\begin{array}{l}.76 \\
.72 \\
.75 \\
.73\end{array}$ & $\begin{array}{l}13.54 \\
12.67 \\
13.32 \\
12.95\end{array}$ \\
\hline
\end{tabular}

(R) Item reverse-coded. All t-values significant at the $1 \%$ level. 